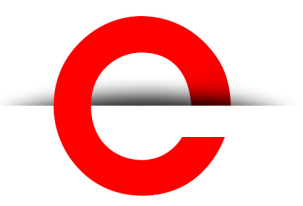

U T S

e PRES S

\section{PORTAL Journal of Multidisciplinary International Studies}

Vol. 14, No. 2

September 2017

Communities Acting for Sustainability in the Pacific Special Issue, guest edited by Anu Bissoonauth and Rowena Ward.

\section{(c) (1)}

(c) 2017 by the author(s). This is an Open Access article distributed under the terms of the Creative Commons Attribution 4.0 International (CC BY 4.0) License (https:// creativecommons.org/licenses/ by/4.0/), allowing third parties to copy and redistribute the material in any medium or format and to remix, transform, and build upon the material for any purpose, even commercially, provided the original work is properly cited and states its license.

Citation: Marks, N. 2017. Population, Reproduction and IVF in New Caledonia: Exploring Sociocultural and Caring Dimensions of Sustainable Development. PORTAL Journal of Multidisciplinary International Studies, 14:2, 6-26. http://dx.doi.org/10.5130/ portal.v14i2.5410

ISSN 1449-2490 | Published by UTS ePRESS | http://portal. epress.lib.uts.edu.au
RESEARCH ARTICLE

\section{Population, Reproduction and IVF in New Caledonia: Exploring Sociocultural and Caring Dimensions of Sustainable Development}

\author{
Nicola Marks \\ University of Wollongong
}

Corresponding author: Dr Nicola Marks, School of Humanities and Social Inquiry, Faculty of Law, Humanities and the Arts, University of Wollongong, Northfields Avenue, Wollongong NSW 2522, Australia. nicola_marks@uow.edu.au

DOI: http://dx.doi.org/10.5130/portal.v14i2.5410

Article History: Received 12/02/2017; Revised 07/05/2017; Accepted 21/05/2017;

Published 05/10/2017

\begin{abstract}
Both sustainability and sustainable development have multiple meanings that are underpinned by diverse normative visions. Nonetheless, sustainable development is currently centre-stage at the global level. The main goal of this paper is to critically examine these important concepts, in particular their social and cultural dimensions, and to make a conceptual offering: that of 'caring sustainable development.'This way of thinking about sustainable development aims to grapple in a situated way with the different normative underpinnings of sustainability in order to support the building of a common future. The paper briefly examines populations, reproduction (both biological and sociocultural) and human in vitro fertilization (IVF), as important sites for thinking about caring sustainable development. It draws on research in New Caledonia examining which populations and which sociocultural practices are encouraged and sustained, or not. It finds that historically there are many examples of things and people being neglected and not cared for, or being encouraged to 'develop' in problematic ways. By contrast, recent practices associated with IVF suggest ways forward that would enable caring sustainable development.
\end{abstract}

\section{Résumé}

La durabilité et le développement durable ont des significations multiples, qui sont soustendues par diverses visions normatives. Néanmoins, le développement durable occupe 
actuellement une place centrale sur le plan mondial. Le but principal de cet article est d'examiner de manière critique ces concepts importants, en particulier leurs dimensions sociales et culturelles, et de faire une contribution conceptuelle qui est celle de la notion du 'care dans le développement durable.' Cette façon de penser au développement durable vise à aborder ces différents fondements normatifs, de façon localisée, pour soutenir la construction à long terme d'un futur commun. L'article examine ensuite brièvement les populations, la reproduction (à la fois biologique et socio-culturelle) et la fécondation humaine in vitro (FIV), en tant que sites importants pour penser à l'idée du 'care' dans le développement durable. Il s'appuie sur la recherche en Nouvelle Calédonie pour analyser quelles populations et quelle pratiques socio-culturelles sont encouragées voire soutenues ou pas. L'article trouve que du point de vue historique, il y a de nombreux exemples de choses et de personnes qui ont été négligées et dont on ne se préoccupait pas, ou alors qui étaient encouragées à se 'développer' de manière problématique. En revanche, les pratiques récentes associées à la FIV suggèrent des moyens d'aller de l'avant qui permettraient de favoriser le 'care' dans développement durable.

\section{Keywords}

\section{New Caledonia; ethics of care; caring sustainable development; stratified reproduction; postcolonialism; assisted reproduction; IVF}

Sustainability and sustainable development are firmly on today's international agenda. For example, in 2015 the United Nations (UN) released seventeen 'Sustainable development goals' or SDGs (United Nations 2015b) to replace the eight 'Millennium development goals' or MDGs from 2000. The SDGs differ from the MDGs in a number of ways. In addition to targeting all states, rather than developing countries, they are more wide-ranging. They aim to promote sustainability in the areas of consumption, cities, industrialization and economic growth (SDG 8, 9, 11 and 12 [United Nations 2015b]), ${ }^{1}$ and to combat hunger, illness, exclusion, discrimination, and environmental degradation (SDG 2, 3, 5, 6, 8 and 16 [United Nations 2015b]). The SDGs include goals relating to sexual and reproductive health services (SDG 3 and 5 [United Nations 2015b]), which were missing from the MDGs (Newman et al. 2014: 53). They also highlight the importance of sociocultural factors, by placing 'culture' at the centre of their aims (UNESCO n.d.) and by referring to three key dimensions of sustainable development: economic, social and environmental (United Nations 2015b: 3).

Recognition by the UN that sustainability and its multiple dimensions are important is worth noting as it points to an appetite for nuanced and multi-faceted approaches to crucial global problems. However, the SDGs have also been criticized for not articulating how, in practice, different issues could be addressed to reach overarching goals, how different stakeholders would be involved, and how competing goals and trade-offs would be managed (International Council for Science \& International Social Science Council 2015: 5-9, 85-86). This is an important limitation as there are many complex and sometimes competing interconnected aspects of sustainable development, for instance when economic development leads to environmental degradation and increased poverty and ill-health.

Of particular relevance to this paper, sustainable development is entangled in intricate ways with reproduction, health and population dynamics; these are areas the UN has struggled with

1 See also United Nations (2015a). It is also worth noting that many of the SDGs are tightly interwoven (International Council for Science \& International Social Science Council 2015). 
U T S

e PRES S

for several decades. In 1994, the International Conference on Population and Development was held in Cairo. According to the conference report, women's empowerment and improved health (which can be partly achieved through education leading to reduced fertility) were important goals in and of themselves, but they were also deemed to be 'essential for the achievement of sustainable development' (United Nations 1994: 22, see also 76). Petchesky, however, identifies 'fault lines' in the Cairo report. Many arguments made by feminists and sexual health advocates seemed to have been heard, but their implementation was made impossible by the focus on 'sustained economic growth' (Petchesky 1995: 157, my emphasis) and by the failure to recognize the broader macro-economic conditions that increase maternal mortality, for instance, and maintain global racialized health and economic disparities.

The above stratifying arrangements need to be 'unsettled' (M. Murphy 2015), and attempts at development, including sustainable development, need to be examined in specific sociocultural, political, economic and historical contexts in order to reveal potential 'fault lines.' In this paper, I first want to make a theoretical contribution to this unsettling by critiquing 'modernist' approaches to sustainable development, such as those that focus on economic development only, and by highlighting why the sociocultural dimensions of development are important. With that aim I propose the concept of 'caring sustainable development.'While the concept does not offer ready-made solutions or lists of how to do sustainable development properly, the notion of caring sustainable development offers ways of noticing and caring for some of the people and sociocultural dimensions that are currently neglected or not sustained. ${ }^{2}$

Second, I want to make an empirical contribution to current debates on sustainability by examining development, sustainability and reproduction in a specific place, New Caledonia, where the interconnectedness of sociocultural and other factors can be crucial. For instance, conservation projects need to be understood against the backdrop of diverse cultural identities, desire for land preservation and economic development, and complex colonial histories (Horowitz 2008). My case study focuses on which populations and which sociocultural practices have been sustained or encouraged to develop.

In what follows, the first section critiques diverse understandings of sustainability and development, and highlights how they are underpinned by different, often competing, normative visions. I argue that the social and cultural dimensions of sustainability, as well as the need to include 'caring,' are important, and propose a concept of sustainability that is multi-faceted, and of development that is nonlinear and not predetermined: 'caring sustainable development.'This concept can work through multiple normative visions and aims to construct a shared world. The next section examines reproduction and population through the lens of caring sustainable development. Here I argue why reproduction, populations and sustainability should be considered together. It examines New Caledonia's history, in particular relationship between settlers from Europe and Indigenous Kanak populations. ${ }^{3}$ The section suggests

2 In this paper, culture is understood in a broad sense as a 'set of beliefs, practices, rituals, and traditions shared by a group of people with at least one point of common identity (such as their ethnicity, race, or nationality)' (Buchanan 2010: 105). The term 'culture' denotes artistic practices, ways of working the land, ways of thinking about family and kinship, and also everyday practices and 'the glue holding society together' (2010: 105). 'Society' refers to 'the ensemble of institutions, organizations, and relationships that give support to the individual' (2010: 441). Although the labels 'social' and 'cultural' are not synonymous, strict distinctions between the two cannot be easily made (2010: 105). In this paper, moreover, I talk about sociocultural sustainability, for example, to signal the focus on maintaining the cultural heritage of diverse groups, and on the diverse institutions and practices that might sustain these groups.

3 I use the label Kanak to refer to Indigenous Melanesian people of New Caledonia. This was the label used by Indigenous people I met there when referring to themselves. 
that there are a number of problematic assumptions around what needs to be sustained, and little evidence of paying attention to those that are neglected. I then turn to recent practices in human in vitro fertilization (IVF) and assisted reproduction in New Caledonia; and I highlight instances of caring sustainable development. The final section concludes with reflections on how caring sustainable development, whilst not a panacea, can be useful in thinking about how New Caledonia might move forward in sustaining and developing diverse groups and sociocultural practices. Here I also make some suggestions about how 'caring sustainable development' might be useful in global discussions of sustainability.

\section{A CONCEPTUAL OFFERING: 'CARING SUSTAINABLE DEVELOPMENT'}

The first formal formulation of sustainable development is usually traced back to the 1987 report 'Our Common Future' (or Brundtland Report, after its chair Gro Harlem Brundtland) released by the UN's World Commission on Environment and Development (or Brundtland Commission). It states:

Sustainable development is development that meets the needs of the present without compromising the ability of future generations to meet their own needs. It contains within it two key concepts:

- the concept of needs, in particular the essential needs of the world's poor, to which overriding priority should be given; and

- the idea of limitations imposed by the state of technology and social organization on the environment's ability to meet present and future needs. (United Nations 1987: 2.1)

This definition is sufficiently vague as to have been taken up in a number of domains, and a range of practices and institutions have been set up in the name of 'sustainable development.' However, this interpretive flexibility has been criticized for rendering the concept meaningless or at least unhelpful (Beckerman 1994; Daly, Jacobs \& Skolimowski 1995; Luke 2005; Springett 2005; Vallance, Perkins \& Dixon 2011). Nonetheless, I will argue here that sustainable development can be understood in practical and politically useful ways.

The idea of sustainability itself is meant to rest on the so-called 'three pillars': economic, sociocultural and environmental. These pillars are often conceptualized as compatible, but this is not necessarily the case (Boström 2012:3). For instance, a number of scholars argue that the main dimension of sustainability that was acted upon, especially in the 1980s and 1990s, was that of economic sustainability, understood as economic growth (Robert, Parris \& Leiserowitz 2005: 11; Redclift 2005: 215). They argue that actions taken in the name of sustainability, but with the goal of economic growth, can be at odds with 'Green' versions of sustainability that favour reduced consumption (Boström 2012: 4). In turn more environmentally focussed versions of sustainability have been criticized for being detrimental to the world's poor, for whom survival, rather than organic foods or hybrid cars, are important on a daily basis. Thus the normative assumptions that underpin different versions of sustainability can be quite contradictory (Redclift 2005: 215).

The sociocultural dimensions of sustainability are arguably those that have been most sidelined (Beckerman 1994; Redclift 2005; K. Murphy 2012). It has been suggested that this is because of some of the inherent conflicts between the different dimensions of sociocultural sustainability. For example, Vallance, Perkins and Dixon argue that there are three types of social-cultural sustainability (they use the label 'social sustainability'). The first aims to reduce 'poverty and inequity'; the second aims to modify 'behaviours so as to achieve bio-physical 
environmental goals'; and the third is about 'the preservation of sociocultural patterns and practices in the context of social and economic change' (2011:345). It is easy to see that some people's desire to preserve a large residential block with room for a garden can be at odds with equity and access to housing for all, and with visions for high density sustainable urban living.

Because of the multiple perspectives on sustainability and its meanings, it becomes clear that when solutions for sustainability are imposed from above they often fail on a number of dimensions that were perhaps not considered relevant initially. This highlights the need to listen to diverse perspectives. As Irwin argues in his discussion of the Brundtland Report: 'there will be no "sustainability" without a greater potential for citizens to take control of their own lives, health and environment.' He then adds that 'success in this goal requires some careful thought about the relations between technical expertise, citizen needs and contemporary culture' (1995: 7). This suggests the importance of locally relevant solutions to global problems. It also highlights how technical solutions alone will not be sufficient. ${ }^{4}$ The different dimensions of sustainability, including sociocultural ones, need to be considered, and voices from diverse people heard and acted upon.

In addition to sustainability, the idea of 'development' has also been problematized. It is often seen to be part of neocolonial efforts whereby less 'developed' countries or peoples need to catch up with the so-called modern world. This conception is too linear, imposes unacknowledged normative views on populations with different perspectives and histories, and leaves very restricted options for 'under-developed' countries and people to become 'developed' (Escobar 1995; Leblic 1993: 10-21). This can even be the case when locals are consulted as part of development efforts (Cooke \& Kothari 2001). This version of development can be called 'modernist development' where new technologies are regarded as apolitical and automatically leading to improved lives for those who adopt them (Leach, Scoones \& Wynne 2005: 7). Technology is contrasted to traditions, customs and culture, which are seen to be backward and in need of modernizing. However, there is increasing evidence that there are multiple ways of being 'developed' and of resisting imposed visions of development, multiple pathways to development, and multiple ways of re-appropriating technologies for development (Escobar 1995; Leach, Scoones \& Wynne 2005).

Therefore, we need a more dynamic conceptualization of development. The type of sustainable development I advocate here does not automatically reject old-fashioned practices as being underdeveloped; nor does it focus on freezing time or attempting to return to or sustain a nostalgic past in which everything seemed better. As Jolly (2002) argues, 'traditional' and 'modern' ways of doing should not be thought of as incompatible. Rather, sustainable development should consider old and new ways of doing, and recognize that practices can be sustained even as they change. In the case study considered below, this means not thinking of Kanak culture as static and 'traditional,' or in need of eradication through westernization or rescuing. It means thinking of settler and Kanak cultures as dynamic, evolving and inextricably linked. This understanding of culture as dynamic can also be found in the words of Jean-Marie Tjibaou, the famous Kanak independence leader, who led fights for political and cultural recognitions of Indigenous peoples in New Caledonia. He advocated a renewal of

4 For example, some scientists and corporations have championed Golden Rice, genetically modified rice fortified in Vitamin A precursor, as a way to prevent blindness in malnourished infants. Jasanoff (2005) discusses how such specific technical approaches are rejected by Green groups, farmers and others who want broader conversations about the apparent corporate take-over of the food chain, postcolonial legacies of inequality, and whether genetically modified products are even desirable, let alone the magic bullets that they are sometimes painted in the media. 
Kanak artistic practices, which would include elements of settler and global practices (Tjibaou 1996: 154-156, see also 42). The measures of success for sustainable development are not simply increased use of technology or increased economic wealth, but are related to locally set community goals, as well as broader goals of equity and inclusion. I elaborate on this below by considering the importance of care and affect.

\section{Caring and sustainability}

Contrary to the modernist idea of development and to versions of sustainability that focus on economic growth, I want to think of sustainable development as flexible and locallysituated (culturally, politically, historically, socially), and as underpinned by different normative visions and commitments. To do this, I draw on discussions about the ethics of care, since they shed light on ways of thinking through potentially conflicting normative visions of both development and sustainability. I draw on Tronto and Fisher, who argue the following:

we need an understanding of caring that allows for contradictions and encompasses the whole range of human activities that serve to sustain us ... we suggest that caring be viewed as a species activity that includes everything that we do to maintain, continue and repair "our world" so that we can live in it as well as possible. That world includes our bodies, ourselves, and our environment, all that we seek to interweave in a complex, life sustaining web. (Fisher \& Tronto 1990: 40, original emphasis)

This way of thinking about caring is particularly attuned to the fact that 'needs' (the word used by Fisher and Tronto, and by the UN) are diverse and variable across time and space. As such, 'the caring process is not a gracefully unfolding one, but [rather it] contains different components that often clash with each other' (Fisher \& Tronto 1990: 40). By grappling with these clashes, and with the 'rich and knotty texture of our caring experience' (Fisher \& Tronto 1990: 40), we can hope to generate locally-situated ways of living in sustainable ways.

This idea of care has been built upon by Puig de la Bellacasa who advocates caring not as an 'accusatory moral stance - if only you would care' (2011: 95, original emphasis), but as a 'commitment to neglected things' (2011: 85; see also Marks \& Russell 2015). Puig de la Bellacasa argues that we can care not only for and with humans, but also for and with multiple others $(2011 ; 2015)$. In practical terms, this can mean observing instances of caring as a starting point. The next step is not to develop universal top-down norms since there is no 'recipe' for caring (Puig de la Bellacasa 2012: 211), but instead to make a commitment to instances of 'ethical doings' (Puig de la Bellacasa 2010: 162). This can involve inviting others to care, practicing care ourselves, making a 'commitment to share troubles and burdens of those who are neglected,' and maintaining the resources (affective and material) that enable caring (Puig de la Bellacasa 2010: 165, original emphasis).

Caring puts affect at the centre of our ways of thinking and doing. Importantly, caring is not thought of here in the traditionally gendered way where care work is feminine work; nor is it something that involves an individual. Rather, caring is about everyday practices that might crystallize in institutions, cultures, or 'even global levels of thinking' (Puig de la Bellacasa 2010: 165-166; see also Tronto 1995: 145). It is not only about doing pleasant things, or things that make us feel happy; caring can also be about culling or killing (Law 2010). Caring reminds us of 'the joint fortunes of all forms of life under socio-technical becomings' (Puig de la Bellacasa 2011: 98) and therefore is central to sustainable development, especially if we accept that there are 'limits,' as posited by the UN's World Commission on Environment and Development (WCED) Brundtland Report (United Nations 1987). 
In addition to caring involving negative affect, positive affect does not automatically lead to the type of caring I am proposing. Certain actions that make us feel good may "work with and through the grain of hegemonic structures, rather than against them' (M. Murphy 2015: 719). For example, as Murphy demonstrates, some instances of feminist engagements with healthcare enabled positive affect by encouraging rich, mostly white US women to attend galas and donate money to support the health of poor, mostly brown women in Africa or Pakistan. These practices fail to attend to the stratified worlds these different groups inhabit, and do not address the colonial legacies that make some women in need of help (M. Murphy 2015: 727-9). Following Haraway (2010), both Murphy (2015: 722) and Puig de la Bellacasa (2012: 704) advocate 'staying with the trouble.'This means paying attention to colonial, racialized and gendered histories, to privilege, and to stratification; it involves 'historicizing' and 'stirring up' 'hegemonic histories' and structures of privilege, and it involves 'reckoning with' them (M. Murphy 2015: 731).

To sum up, my suggestion for caring sustainable development is to examine specific attempts at sustainability or development, and to pull out context-based ways of caring (these may be conflicting), make them visible, and highlight what ways of being or doing are being sustained. It invites, as Puig de la Bellacasa puts it, people to respect each other's ways of caring in order to 'build a common world' (2011: 88), to 'foster caring relations' (2011: 97), and to 'share the burden of stratified worlds' (2011: 94). These examinations need to consider and unsettle hegemonic structures, especially those that impose unsatisfactory ways of being onto silenced or oppressed others. Caring sustainable development is situated though, and criteria for success will vary. However, by tracing different instances of caring (and lack thereof), one can extract what might be assembled to generate further caring relationships, and perhaps enable the equity and inclusion discussed in the previous section.

\section{Reproduction, populations, culture and sustainability}

Reproduction, including reproductive and sexual health, is worth examining through the lens of caring sustainable development because of its multiple interconnected dimensions, such as gender equity, cultural norms and population dynamics. Newman et al. (2014) argue that advocates for gender equality and reproductive rights need to find ways of talking effectively with those who are focussed on the environment, food security and demographic changes, including urbanization and household composition, because none of these issues can be understood in isolation. Indeed, reproduction can include individual access to contraception, pregnancy care, infancy care, or fertility treatments. However, reproduction is also about population birth rates and death rates, fertility rates, or fecundity rates. It is correlated with education levels and gender equality (educated women have fewer children), job opportunities and poverty (paternal and maternal income can influence fecundity), as well as environmental factors (semen quality can be affected by pollution) or cultural norms (expectations of bearing large or small numbers of children, or cultural taboos surrounding sexuality leading to increased sexually transmissible diseases and reduced fertility). There are many social determinants of human reproduction (ESHRE Capri Workshop Group 2001) as well as fertility changes due to environmental conditions (Association of Reproductive Health Professionals 2010).

The environment can be affected by fertility. One of the earliest and perhaps most notorious discussion of this is in The Limits to Growth: A Report for the Club of Rome's Project on the Predicament of Mankind (Meadows et al. 1972) which examined the interaction between global population growth and pollution, resources, industrialization and food production. The book 
received strong criticisms as well as support (Sandbach 1978; Turner 2008). The link between population and sustainability is still widely debated; some people advocate ways of curbing population growth (Smail 2002), whilst others see these approaches as impractical (Bradshaw \& Brook 2014) or ethically problematic (Newman et al. 2014).

Assisted reproduction and infertility treatments have also been linked to sustainability. Richie (2015) argues that in order to be sustainable, countries need to stop supporting assisted reproductive technologies, especially where there is no biological reason for infertility. This stands in contrast to those who have raised concerns about the inequalities in access to infertility treatments and support in low resource countries (Inhorn 2009). An 'infertility belt' has been documented in Africa (Inhorn \& van Balen 2002), and the silence from Western countries surrounding infertility in third world countries has been criticized, as has the 'tacitly eugenic view that the infertile poor are unworthy of treatment' (Birenbaum-Carmeli \& Inhorn 2009a: 6). There are also heavy social and economic consequences to remaining childless in a number of countries (Birenbaum-Carmeli \& Inhorn 2009b; Inhorn \& van Balen 2002).

If we take seriously Bellacasa's invitation to relate with multiple others and to foster 'caring relations' especially with those who are neglected, then the question of who is and who is not 'worthy' of reproducing becomes central to a caring, rather than modernist, approach to sustainable development. We also need to consider what is being reproduced, both with assisted and non-assisted reproduction. A number of social scientists have argued that when we make kin, that is when we reproduce, we are reproducing much more than biological features such as genes: we are also reproducing society and culture (Strathern 1992; Franklin \& Ragone 1998). For instance, we might be reproducing and normalizing specific assumptions about what the ideal family looks like (the nuclear family for instance), and these assumptions may be deeply racialized or exclusionary.

We can thus see the multiple, at times contrary, normative commitments underlying different visions of the relationship between sustainability and (assisted) reproduction. That relationship pushes us to consider who and what is being sustained or developed in different visions of sustainable development. Are certain modes of sustainable development reproducing particular cultural perspectives at the expense of others? Is the expansion of neo-liberal economics eradicating local cultures and ways of being? Are some versions of development too narrow, hegemonic, racist or stratifying? These are some of the questions I seek to answer through my case study of New Caledonia.

I now turn to a selection of episodes from New Caledonia's history to suggest some of the complex ways in which population control, reproduction, cultural practices, normative assumptions about specific people, and visions of development are connected in complex ways to sustainability. I then examine the contemporary example of IVF practice. I draw on a range of secondary sources including public health reports, reports on employment data, case studies of Indigenous development, and historical analyses of settler-Indigenous relations. I also draw on primary sources including census data, law texts and interviews. The interviews took place in 2016 with four key professionals who are involved in healthcare, three of them directly in IVF. While the interview numbers are very small they represent most of the core-set of people providing infertility services in New Caledonia, as they are the crucial gate-keepers to these services. One interview respondent was Kanak and provided very interesting insights, even though these clearly cannot be taken as representing the Kanak population in any way. 
Patients were not interviewed, as the data presented here are part of a broader project aimed at understanding professional views on $\mathrm{IVF}^{5}$

\section{A history of populations and sociocultural sustainability in New Caledonia}

New Caledonia is a French Overseas Country: it has relatively high levels of administrative independence from France, but is on the UN list of countries in need of decolonization (United Nations 2016). A referendum is set to take place in 2018 on full independence. At the last census, people from a range of communities were counted: 39 percent Indigenous Kanak, 27 percent European, 8 percent from the Territory of the Wallis and Futuna Islands, 8.6 percent 'mixed communities,' and 7.4 percent 'Caledonians' (ISEE 2014). The country is relatively rich and has a high GDP (especially in comparison to its Pacific Island neighbours), but the economy is strongly propped up by France. There is free education and free healthcare for all, following French principles of equality. However, income, mortality, employment, health and other factors are unevenly distributed, as I discuss below. To understand this, it is essential to consider New Caledonia's colonial heritage, as well as present day socio-political configurations.

New Caledonia was settled by the French in 1853. It began mainly as a penal colony (discussed by Pascual [2017] in this issue), until the discovery of nickel in 1875. Today, New Caledonia is the world's $5^{\text {th }}$ largest nickel producer, and nickel accounts for 97 percent of the value of the country's exports. If we were examining this history, paying attention only to economic growth, we would see multiple examples of economic development, especially with the nickel mine and the huge riches enjoyed by absentee landlords such as Maison Ballande who own much New Caledonian land but have never come to New Caledonia (Kohler \& Shineberg 1992). Taking a caring sustainable development lens, we see a number of ways in which there were neglected others, hegemonic colonial structures, and heavy stratification; we can pay attention to ways in which some people and things were not cared for.

The French always had a fraught relationship with Indigenous Kanak populations. As early as 1856, Commander Testard, responsible for the colony, described the Indigenous person as 'intelligent, but a monster of perversity.' He then went on to argue: 'We must start by destroying this population if we want to live in security in this country' (cited in Goblot 1985: 108). From 1859, Kanak people were displaced by the settler government into reservations and there was an assumption that they would die out, partly because of natural evolution (Leenhardt, cited in Tjibaou 1996: 49). While early census figures are unreliable (Shineberg 1986; Leblic 1993: 60), it seems that Kanak numbers dipped significantly after the arrival of European settlers, falling from an estimated 60,000 in 1853 to 27,100 in 1921 (Munholland 2005). Kanak people still accounted for the majority of the population until 1956 (Leblic 1993: 30-32), except for the 1946 census when they briefly were a minority.

The Kanak were offered very few economic development opportunities. Under France's 'Code de l'Indigénat' [Code of the Indiginate], which lasted from 1887 until after the Second World War, they were subject to strict curfew and restrictions on movements. Kanak also had to pay taxes to settlers, usually in the form of free labour. Even though cheap/free labour was needed after the discovery of nickel, the French preferred to bring in other islanders who were seen as more reliable (Shineberg 1999). Indigenous people only became full French citizens and were able to vote in local, as well as French presidential and other elections, from 1953.

5 The research was approved by the University of Wollongong Human Research Ethics Committee. 
This mistreatment has led to a number of clashes between European and Kanak populations, and several strong calls for independence, most recently during 'Les Évènements' [The Events] from 1984 to 1988 . Many revolts were violently crushed. Overall, there has been what Leblic (1993: 53-74) calls 'La Valse des Statuts' [The Waltz of Statutes], whereby successive French governments have given and reclaimed powers to and from local authorities (including Kanak groups), have tried to include Indigenous people in New Caledonian life, but have also tried to quash calls for independence.

Strategies to maintain French control over New Caledonia have partly focussed on populations and reproduction, as hinted at above. In 1972, there was an infamous directive from the then French Prime Minister, Pierre Messmer, to build an additional French country in the Pacific by encouraging migration of French nationals from mainland France, Tahiti and Reunion to New Caledonia, and by countering the nationalistic advances the Kanak people were making at the time. This directive aimed explicitly to reduce the overall percentage of the Kanak population so that it could not influence elections. The same year, the mayor of Nouméa (the capital of New Caledonia) asked French people to 'faire du Blanc' [make some white] (Leblic 1993: 30-32). Reproduction and populations are thus key political sites in the territory.

In addition to vast reductions in the Kanak population, their ways of being and doing were threatened. For instance, the French language was imposed in all schools from 1853, and the teaching of all other languages was banned from 1863. We also see, contrary to Irwin's (1995) urging raised above, little evidence of Kanak people being given opportunities 'to take control of their own lives, health and environment,' therefore making any goals of 'sustainability' harder to achieve.

This is especially visible when we consider land rights. When European settlers seized New Caledonian lands and sent Kanak people off to reservations, they failed to consider the strong relationships Kanaks have with the land; these relations shape a range of sociocultural practices (see Pascual [2017] in this issue). This is, in part, because of a widely held belief that Kanak people did not know how to look after the land, and had neither agricultural practices (Shineberg 1986) nor a concept of land ownership (Leblic 1993). This has been shown to be untrue: Kanak people grow crops that are essential not only for food, but also for gifts and exchanges at important occasions (such as marriages). There are also codified ways in which people can work the land (with particular clans linked to particular lands) and complex irrigation systems that are integrated into the existing ecosystems.

Other moments of New Caledonian history do suggest attempts to bring Kanak and other populations together. There have been a number of attempts at 'development' as well as devolution of powers to Kanak leaders. However, these were often deemed failures by the European settlers or the French metropolitan sponsors. Such opinions reflect diverging criteria for success, a lack of recognition of the impact of colonization, and sometimes a lack of good will in acknowledging success. For example, in 1986, after a swell in support for independence, the French government devolved a number of responsibilities to local New Caledonian governments, including health. Local Kanak-led governments developed healthcare in many remote places, and invested in disease prevention and public health education. This was essential since outside Nouméa there were very few health facilities. ${ }^{6}$ Despite initial positive results, this devolution was soon reversed by the French government, due to a desire to block

6 In addition, historically the Kanak had not been treated in the same hospitals as settlers, instead undergoing treatment in the Indigenous hospital in the capital. 
further moves towards Kanak independence (Leblic 1993: 218-24). So success from the point of view of improving Kanak health for instance was ignored, and the normative commitment to maintaining the integrity of the empire dominated; only colonial ways of doing were sustained and cared for.

Clashing normative commitments are also visible in attempts at Kanak economic development. Leblic (1993) argues that these were dominated by European visions of development, whereby Kanak people were thought of as archaic and needing better assimilation into the New Caledonian economy. Many of the solutions (grants for local projects to support economic development) did not lead to increased integration of Kanak people into the broader economy, or to commercial crops. The projects were deemed failures by the European sponsors. This can be attributed to a disregard for the historical stratification and colonial heritage of stolen lands, which was accompanied by the destruction of many dimensions of local culture. Most interestingly, however, many of the Kanak did not see these projects as failures, because they judged them by different criteria. For them the goal was often to regain their lands. If that meant having to apply to conduct a project on it, such as grow coffee, a crop not traditionally grown there and which locals said they did not 'care' for in the same way, so be it. Whether the coffee brought them money or not did not matter, only the land did.

The above is an example of sustaining or regaining access to particular cultural practices (Leblic 1993: especially 389-397). Even though the land practices were not the same as before colonization, if we accept that culture is dynamic rather than frozen, we can see Kanak culture being sustained through a cooptation of colonial structures. The festival Melanesia 2000 can be understood in a similar light, although it is a much more obvious success story of sustainable Kanak ways of being and doing. Melanesia 2000 took place in 1975 in Nouméa (earlier than the above examples); it was the first festival in the world to celebrate Melanesian art. Over 2,000 Kanak people attended, and there were 50,000 audience members (Tjibaou 1996: 48). Kanak independence leader Jean Marie-Tjibaou explains that the festival occurred at a historical moment when Kanak people were excluded from social and economic life and when discussions of devolution were stalling. Nonetheless it ended up a huge success, and was recognized internationally and, perhaps more importantly, by local Kanak and regional Melanesian groups. Kanak people had initially been reluctant to participate because they saw this as a colonial project; it was funded through the colonial Administration and the French government initially saw it as a way to regain authority over Kanak people (Tjibaou 1996: 152). But the aims of Tjibaou and others to make this festival about the Kanak people and to enable cultural 'renaissance' were successful (Tjibaou 1996: 42-43, 152). Increased Kanak recognition followed, and land reform proceeded, albeit slowly. However, in 1986, a new right wing president, Jacques Chirac, was elected in metropolitan France and reform once again stalled.

Despite some examples of Kanak ways of doing being sustained, this section shows the significance of (post)colonial arrangements in neglecting Kanak people. The ways in which things were cared for, and the kinds of things that were cared for, often ran with the grain of these hegemonic structures, to use M. Murphy's words (2015): they sustained economic enrichment (of some) and supported modernist sustainable development, usually at the expense of Kanak people. There were few attempts at 'building a common world' (Puig de la Bellacasa 2011: 88) that included Indigenous peoples and their ways of being and living. 


\section{Ethical doings for sustainability in relation to reproduction and IVF today}

Given the episodes noted above, in which Kanak populations were seen as a threat to the French empire, it would seem likely that Kanak peoples would not be encouraged to reproduce, and would not be imagined as recipients of assisted reproductive technologies such as IVF. However, this is not the case today.

Kanak populations, especially those living away from the capital are still over-represented in early deaths. But they have higher fecundity levels than European settlers (ISEE 2012). ${ }^{7}$ Kanak people also have high levels of sexually transmitted diseases (Direction des Affaires Sanitaires et Sociales 2014). These diseases are considered either to be 'white man's disease'which reflects colonial historical contexts—or women's diseases—which reflects local sociocultural contexts (Salomon 2000a). This results in women carrying the burden for these diseases, in diseases not being treated in men, and in high rates of disease; this, in turn, can lead to decreased fertility. In parallel, there is strong pressure on Kanak women to become mothers, which Salomon calls 'obligatory maternity' (2002). In combination, it is likely that involuntary childlessness levels are high. However, being infertile is taboo, leading to delays in accessing treatment and further chances of reduced fertility. It is vital, then, to explore to what extent involuntary childlessness in a group of historically marginalized people is being addressed.

In many countries around the world assisted reproduction is big business (Spar 2006; Cooper \& Waldby 2014), and its use is heavily stratified along ethnic or economic lines (Inhorn, Ceballo \& Nachtigall 2009; Mamo \& Alston-Stepnitz 2015). However, the situation is very different in New Caledonia. Because the health system is based on the French one, it is public, and there are very generous provisions for access to infertility treatment. This includes at least four cycles of IVF, reimbursed to 90 percent. This is much more than many European countries (Berg Brigham et al. 2013). In addition to this, beside the hospitalization for egg retrieval and then embryo implantation, all the drugs, early consultations and blood tests are covered. Also covered are transport costs for treatment, and this includes travel from the smaller islands to Nouméa where the fertility centre is located. ${ }^{8}$ From this we can see that all people, including those with lower incomes and who live further away from the capital, are able to access IVF. This includes many Kanak people who still have higher levels of unemployment and financial insecurity than the national average (Ris 2013), and marks a big difference from the 1970s when there was a wish for white people to migrate to New Caledonia and reproduce.

In addition, during interviews, health professionals involved in infertility services expressed an explicit aim of ensuring Kanak people having access to treatment. This includes high-tech IVF, and IVF doctors regularly travel to the islands and their dispensaries in order to consult with a range of Kanak women. They do this in a culturally sensitive way, and do not advertise that they are infertility specialists, but rather set up more generic women's health consultations. Local midwives and word-of-mouth are essential here in letting women know they can discuss their fertility concerns. There are also lower technology interventions such as education

7 This is an estimate, based on using place of residence as a proxy for ethnicity, since collecting data linking ethic origin and health is problematic in New Caledonia.

8 There is only one infertility centre in Nouméa, with a chief biologist, a medical doctor and a technician. There are two main private IVF providers in the capital. Most of the medical interventions legg retrieval and embryo implantation) take place in the hospital in Nouméa, regardless of whether the patient is private or public. 
regarding sexually transmitted diseases. In addition, some IVF practitioners are conducting research in order to develop medical protocols for IVF that are specifically adapted to Kanak women (for example specially adapted drug dosages).

These examples clearly go against the historical attempts at eradicating Kanak populations; rather they indicate how the population is being sustained. But is this at the cost of Kanak ways of being and doing? The answer is complex. On the one hand, there are some shifts away from 'traditional' ways of doing towards Western ones. On the other hand, 'traditional' ways are evolving into new contemporary Kanak ways of doing. As I suggested above, it is artificial to separate 'traditional' and 'modern'/'Western,' or 'under-developed' and 'developed' (Leblic 1993). Therefore, it is problematic to assume that any adoption of new ways of doing is necessarily at the cost of Kanak culture. Rather, as with all cultures, Kanak culture evolves in dynamic ways. We saw an example of this above with the use of 'modern' economic development plans to regain access to land. The creation and renewal of ways of doing also need to be examined in the context of new reproductive technologies.

While those couples who consult for assisted reproduction are low in number, according to health practitioners in the island dispensaries there is some evidence of growing knowledge about IVF, and of interest in the options it offers to counter involuntary childlessness ${ }^{9}$. This does not mean, however, that customary medicine is being replaced by so-called Western or modern medicine. Indeed, while the two have had an uneasy co-habitation (Salomon 2000b; Jolly 2002), traditional medicine is recognized and its qualities accepted in some circles (Lormée, Cabalion \& Hnawia 2011). In many instances, old and new ways of doing medicine are blended (Lepoutre 2000).

In the context of reproduction and creating families, the Kanak health professional I interviewed suggested there was a shift towards more individualism amongst young Kanak people. Customary adoption, which still occurs in New Caledonia, places a different emphasis on biological ties, compared to 'Western' understandings of kinship. Indeed, it is common for children to be adopted by others in the community: by a childless couple; by a maternal uncle; by another group. These open adoptions are done according to complex social and cultural norms (Leblic 2000; 2003). Thus any move towards assisted reproduction with the expectation of creating genetically related kin can be interpreted as a move away from Kanak culture. However, this Kanak health professional emphasized that assisted reproductive technologies and Kanak culture were not incompatible. In fact she suggested the importance of moving forwards, as Caledonians, whether or not independence was the outcome of the 2018 referendum, and of finding ways of doing biological, social and cultural reproduction to reflect Kanak as well as European practices. One suggestion was to rethink the anonymity of sperm donation (imposed from mainland France) to better take into account Kanak conventions of not masking one's genealogy. Caring sustainable development, then, would be possible by assembling both Kanak and settler views into future practices and policies surrounding assisted reproduction.

9 This interest parallels shifts seen more generally in young Kanak people, women especially, who are turning towards French laws rather than customary ones to resolve disputes about family violence (Salomon 2003). 


\section{Conclusions}

This paper opened by discussing the UN sustainable development goals, as an illustration of the apparent international interest in sustainable development and its interconnected sociocultural, economic and environmental dimensions. However, these dimensions can be opposing and attempts at sustainable development may only support some dimensions, whilst failing to address broader stratifying elements. Therefore, it is timely to examine some examples of development and sustainability in practice and to conceptually refine the idea of sustainable development. This paper has attempted to do both these things, in order to contribute to unsettling stratifying arrangements.

I have accordingly critiqued modernist versions of sustainable development, which tend to have a reductive focus on economic growth, and imagine development as linear, without recognising the dynamism of different cultures and ways of doing, and the multiple pathways to (and end-points of) development. Instead, I proposed the concept of 'caring sustainable development.' This concept echoes the recent global recognition of the interconnectedness of economic, environmental and sociocultural factors, and their importance in trying to address complex issues such as poverty, sustainability and equity. To that, my concept adds a commitment to constructing and looking after a shared world, through ongoing support for caring practices. This builds on recent scholarship on caring and affect, which urges us to pay attention to multiple, often neglected, others, as well as to the historically-situated sociocultural arrangements that may stratify or exclude (Puig de la Bellacasa 2010; M. Murphy 2015).

Caring sustainable development inspires us to observe examples of caring and sustaining in particular situations. Here, the case study was New Caledonia, specifically the ways in which populations and sociocultural practices are enmeshed in intricate ways and have (or not) been sustained. New Caledonia is a place with complicated (post-)colonial relations. Looking at historical events, we can see that policies and practices aimed at shifting Indigenous versus settler population numbers as well as Indigenous versus settler ways of being and doing have been key political sites, including during fights for independence. My analysis identified many instances when Kanak ways of being and doing were not sustained, but colonial ones were, for instance when Indigenous lands were seized by absentee landlords, or when white people were encouraged to immigrate to New Caledonia and to have children. These were examples of exclusion and many attempts at development reproduced settler colonial practices at the expense of Indigenous ones. There were examples of neo-liberal economics attempting to eliminate Indigenous ways of doing. These versions of development were narrow and hegemonic; some of them were explicitly racist.

There were also examples of colonial and neo-liberal arrangements being co-opted for Indigenous purposes. For instance, some Kanak people were successful at regaining access to their lands by applying for French-supported development funds and setting up coffee plantations. If we see Kanak culture as dynamic, rather than static, these examples show ways in which Kanak culture could be sustained, even though it changed. However, the modernist normative visions often took over again, and projects seen as successes by Indigenous people were labelled failures by their neo-liberal sponsors, and were not maintained (cared for and sustained) into the future. A more complex example is that of Melanesia 2000, which marked an important moment in Kanak cultural renaissance, but which also took place just before yet another halt in the devolution of powers to Kanak people. 
These aspects of New Caledonia's history suggest many ways in which its Indigenous population's sociocultural customs were not cared for, developed or sustained. However, recent practices in assisted reproduction offer possibilities for caring sustainable development. The core team responsible for fertility services in New Caledonia is committed to sustaining Kanak reproduction. The team is focused on biological reproduction, but in a way that does not dismiss Kanak ways of doing, and that is not hegemonic or stratifying. If we accept that Kanak culture can change without being lost, and that Indigenous ways of doing are not automatically in opposition to 'modern' or technical ways of doing, assisted reproduction in New Caledonia offers an example of caring practices: helping infertile people and sharing their burden, regardless of their ethnic and economic background, without dismissing cultural taboos about infertility.

New Caledonia is at a turning point in its history. There are multiple moments in which the future of the country will be discussed and decided upon, including the vote on independence scheduled for 2018. Based on the findings presented forward here, there are examples of ethical doings and of caring sustainable development that can be further built upon. This might include drafting a Caledonian Bioethics Law (rather than just importing a law from mainland France) that recognizes particular Kanak ways of thinking about kinship and genealogy when dealing with gamete donation for assisted reproduction. This is one way in which every day caring practices might crystallize into institutions (Puig de la Bellacasa 2010: 165-166).

In the 2009 census, a 'Caledonian' category was added to the section regarding to which community people belong. One interpretation of this (and certainly partly true) is a cynical one that suggests the shift was aimed at making it impossible to compare different census figures and see the relative decline in Kanak populations. However, this category, which is growing - it went from 5 percent in 2009 to 7.4 percent in 2014 (Broustet \& Rivoilan 2015) can perhaps be a symbol of moving to 'build a common world' (Puig de la Bellacasa 2011: 88) in New Caledonia, and also more globally.

What broader lessons can we learn from these examples? A central message is that caring sustainable development will look different in different situations. However, there are elements that policy-makers in the UN with an interest in tackling complex problems like sustainability might find useful. The first is making spaces for and paying attention to multiple voices, especially those that are traditionally neglected, and recognizing that there are multiple normative visions for development and sustainability. This cannot be done with something like a one-off focus group: it requires enduring commitment. The second is highlighting arrangements that can be stratifying or exclusionary (such as colonial institutions), challenging them, and sharing the burdens they result in. The third is providing support for caring ways of doing. This includes ongoing financial support, but also more symbolic support such as recognising the importance of local practices and not treating 'traditions' as backward or in need of development. A final element important for caring sustainable development is the acknowledgement of different criteria for success, and the integration of these criteria into decisions on whether or not to continue with particular ways of doing. These suggestions are not offered as a list of things to do that, if ticked off, signal an end to our work because we are 'doing things right'; rather they are meant to encourage us to worry about what 'doing the right thing' looks like (Jansen \& Roquas 2005: 147). These elements can be assembled in diverse situated ways into a 'life sustaining web' (Fisher $\&$ Tronto 1990: 40) 
U T S

\section{Acknowledgements}

The research for this paper was funded by an ARC Discovery grant (DP 150101081), for a project entitled IVF and Assisted Reproductive Technologies: The Global Experience. I would like to thank my co-chief investigators Sarah Ferber and Vera Mackie for productive discussions about this work, and Rowena Ward and Anu Bissoonauth-Bedford who organized the round-table on sustainability in the Pacific where I presented an earlier version of this paper and who were fantastic in supporting my contribution to this special issue. Thanks also to the anonymous reviewers and the editor of Portal for their useful and insightful suggestions. Most importantly, thank you to the people who accepted to be interviewed for this research.

\section{References}

Association of Reproductive Health Professionals 2010, Environmental Impacts on Reproductive Health. Online, available: http://www.arhp.org/Publications-and-Resources/Clinical-Proceedings/RHE [Accessed 3 February 2017].

Barrera, P. 2017, '10 Top Nickel-Producing Countries.' Online, available: http://investingnews.com/daily/ resource-investing/base-metals-investing/nickel-investing/10-top-nickel-producing-countries/ [Accessed 17 May 2017].

Beckerman, W. 1994, “Sustainable Development”: Is it a Useful Concept?,' Environmental Values, vol. 3, no. 3: 191-209. https://doi.org/10.3197/096327194776679700

Berg Brigham, K., Cadier, B. \& Chevreul, K. 2013, 'The Diversity of Regulation and Public Financing of IVF in Europe and Its Impact on Utilization,' Human Reproduction, vol. 28, no. 3: 666-675. https://doi. org/10.1093/humrep/des418

Birenbaum-Carmeli, D. \& Inhorn, M. C. (eds) 2009a, Assisting Reproduction, Testing Genes: Global Encounters with New Biotechnologies. Berghahn Books, Oxford.

Birenbaum-Carmeli, D. \& Inhorn, M. C. 2009b, 'Masculinity and Marginality: Palestinian Men's Struggles with Infertility in Israel and Lebanon,' Journal of Middle East Women's Studies, vol. 5, no. 2: 23-52. https://doi.org/10.2979/MEW.2009.5.2.23

Boström, M. 2012, 'A Missing Pillar? Challenges in Theorizing and Practicing Social Sustainability: Introduction to the Special Issue,' Sustainability: Science, Practice, E Policy, vol. 8, no. 1: 3-14.

Bradshaw, C. J. A. \& Brook, B. W. 2014, 'Human Population Reduction Is Not a Quick Fix for Environmental Problems,' Proceedings of the National Academy of Sciences, vol. 111, no. 46: 16610-16615. https://doi.org/10.1073/pnas.1410465111

Broustet, D. \& Rivoilan, P. 2015, Recensement de la population en Nouvelle-Calédonie en 2014: Une démographie toujours dynamique [2014 Population Census in New Caledonia: Still a Dynamic Demography]. Online, available: https://www.insee.fr/fr/statistiques/1560282 [Accessed 30 January 2017].

Buchanan, I. 2010, A Dictionary of Critical Theory. Oxford University Press, Oxford.

Cooke, B. \& Kothari, U. (eds) 2001, Participation: The New Tyranny? Zed Books, London \& New York.

Cooper, M. \& Waldby, C. 2014, Clinical Labor. Duke University Press, Durham, NC. https://doi. org/10.1215/9780822377009 
Daly, H., Jacobs, M. \& Skolimowski, H. 1995, 'Discussion of Beckerman's Critique of Sustainable Development,' Environmental Values, vol. 4, no. 1: 49-70. https://doi.org/10.3197/096327195776679583

Direction des Affaires Sanitaires et Sociales 2014, Situation sanitaire en Nouvelle Caledonie: Les infections sexuellement transmissibles [The Public Health Situation in New Caledonia: Sexually Transmitted Infections]. Online, available: http://www.dass.gouv.nc/portal/page/portal/dass/librairie/ fichiers/32142252.PDF [Accessed 29 January 2017].

Escobar, A. 1995, Encountering Development: The Making and Unmaking of the Third World. Princeton University Press, Princeton, NJ.

ESHRE Capri Workshop Group 2001, 'Social Determinants of Human Reproduction,' Human Reproduction, vol. 16, no. 7: 1518-1526. https://doi.org/10.1093/humrep/16.7.1518

Fisher, B. \& Tronto, J. 1990, 'Toward a Feminist Theory of Caring,' in Circles of Care: Work and Identity in Women's Lives, (eds) E. K. Abel \& M. K. Nelson. State University of New York Press, Albany: 36-54.

Franklin, S. \& Ragone, H. 1998, Reproducing Reproduction: Kinship, Power, and Technological Innovation. University of Pennsylvania Press, Philadelphia.

Goblot, L. 1985, 'Un livre sur la Nouvelle-Caledonie: "La terre est le sang des morts" [A Book on New Caledonia: "The Land is the Blood of the Dead"], Peuples Noirs Peuples Africains, vol. 44: 103-142.

Haraway, D. 2010, 'When Species Meet: Staying with the Trouble,' Environment and Planning D: Society and Space, vol. 28, no. 1: 53-55. https://doi.org/10.1068/d2706wsh

Horowitz, L. S. 2008, "It's Up to the Clan to Protect": Cultural Heritage and the Micropolitical Ecology of Conservation in New Caledonia,' The Social Science Journal, vol. 45, no. 2: 258-278. https://doi. org/10.1016/j.soscij.2008.03.005

Inhorn, M. C. 2009, 'Right to Assisted Reproductive Technology: Overcoming Infertility in LowResource Countries,' International Journal of Gynecology E Obstetrics, vol. 106, no. 2: 172-174. https://doi. org/10.1016/j.ijgo.2009.03.034

Inhorn, M. C., Ceballo, R. \& Nachtigall, R. 2009, 'Marginalized, Invisible, and Unwanted: American Minority Struggles with Infertility and Assisted Conception,' in Marginalized Reproduction: Ethnicity, Infertility and Reproductive Technologies, (eds) L. Culley, N. Hudson \& F. van Rooij. Earthscan, London \& Sterling, VA: 181-197.

Inhorn, M. C. \& van Balen, F. (eds) 2002, Infertility Around the Globe: New Thinking on Childlessness, Gender, and Reproductive Technologies. University of California Press, Berkeley.

International Council for Science \& International Social Science Council 2015, Review of Targets for the Sustainable Development Goals: The Science Perspective. Online, available: https://www.icsu.org/ cms/2017/05/SDG-Report.pdf [Accessed 10 June 2017].

Irwin, A.1995, Citizen Science: A Study of People, Expertise and Sustainable Development. Routledge, London.

ISEE 2012, Bilan 2012: Naissances-fecondité [2012 Evaluation: Births-Fertility]. Online, available: http:// www.isee.nc/population/demographie/naissances-fecondite [Accessed 13 September 2017].

ISEE 2014, Recensement 2014: Structure de la population et evolutions [Census 2014: Population Structure and Trends]. Online, available: http://www.isee.nc/population/recensement/structure-de-la-populationet-evolutions [Accessed 13 January 2017]. 
Jansen, K. \& Roquas, E. 2005, 'Absentee Expertise: Science Advice for Biotechnology Regulation in Developing Countries,' in Science and Citizens: Globalization and the Challenge of Engagement, (eds) M. Leach, I. Scoones, \& B. Wynne. Zed Books, London: 142-155.

Jasanoff, S. 2005, “Let Them Eat Cake”: GM Foods and the Democratic Imagination,' in Science and Citizens: Globalization and the Challenge of Engagement, (eds) M. Leach, I. Scoones, \& B. Wynne. Zed Books, London: 183-198.

Jolly, M. 2002, 'Introduction: Birthing Beyond the Confinements of Tradition and Modernity?,' in Birthing in the Pacific: Beyond Tradition and Modernity?, (eds) V. Lukere \& M. Jolly. University of Hawai'i Press, Honolulu: 1-30.

Kohler, J.-M. \& Shineberg, D. 1992, 'Argent, religion et pouvoir en Nouvelle-Calédonie. A. Ballande et les évêques, 1885-1935' [Money, Religion and Power in New Caledonia. A. Ballande and the Bishops, 1885-1935], Journal de la Société des Océanistes, vol. 95, no. 2: 151-183. https://doi.org/10.3406/ jso.1992.2617

Law, J. 2010, 'Care and Killing: Tensions in Veterinary Practice,' in Care in Practice: On Tinkering in Clinics, Homes and Farms, (eds) A. Mol, I. Moser, \& J. Pols. Transcript Verlag, Bielefeld: 57-72. https://doi.org/10.14361/transcript.9783839414477.57

Leach, M., Scoones, I. \& Wynne, B. (eds) 2005, Science and Citizens: Globalization and the Challenge of Engagement. Zed Books, London.

Leblic, I. 1993, Les kanak face au développement: La voie étroite [Kanaks in the Face of Development : The Narrow Path]. Presses Universitaires de Grenoble, Grenoble.

Leblic, I. 2000, 'Adoption et transferts d'enfants dans la région de Ponérihouen' [Adoption and Transfer of Children in the Ponérihouen Region], in En pays kanak; Ethnology, linguistique, archéology, histoire de la Nouvelle Calédonie [In Kanak Country; Ethnology, Linguistics, Archaeology, History of New Caledonia], (eds) A. Bensa \& I. Leblic. Maison des Sciences de l'Homme, Paris: 49-68. https://doi.org/10.4000/ books.editionsmsh.2772

Leblic, I. 2003, 'D'une famille à l'autre: circulation enfantine kanak en NC' [From one family to another: The circulation of Kanak children], presented at 6ème congrès du GREPFA, 15-16 May, Grenoble.

Lepoutre, M. 2000, 'Le pluralism médical à Lifou' [Medical Pluralism in Lifou], in En pays kanak; Ethnology, linguistique, archéology, histoire de la Nouvelle Calédonie [In Kanak Country; Ethnology, Linguistics, Archaeology, History of New Caledonia], (eds) A. Bensa \& I. Leblic. Maison des Sciences de l'Homme, Paris: 293-310. https://doi.org/10.4000/books.editionsmsh.2797

Lormée, N., Cabalion, P. \& Hnawia, É. S. 2011, Hommes et Plantes De Maré, Îles Loyauté NouvelleCalédonie [People and Plants of Maré, Loyalty Islands, New Caledonia]. Institut de recherche pour le développement, Marseille.

Luke, T. W. 2005, 'Neither Sustainable Nor Development: Reconsidering Sustainability in Development,' Sustainable Development, vol. 13, no. 4: 228-38. https://doi.org/10.1002/sd.284

Mamo, L. \& Alston-Stepnitz, E. 2015, 'Queer Intimacies and Structural Inequalities: New Directions in Stratified Reproduction,' Journal of Family Issues, vol. 36, no. 4: 519-540. https://doi. org/10.1177/0192513X14563796

Marks, N. J. \& Russell, A. W. 2015, 'Public Engagement in Biosciences and Biotechnologies: Reflections on the Role of Sociology and STS,' Journal of Sociology, vol. 51, no. 1: 97-115. https://doi. org/10.1177/1440783314562503 
U T S

e PRES S
Meadows, D. H., Meadows, D. L., Randers, J. \& III, W. W. B. 1972, The Limits to Growth: A Report for the Club of Rome's Project on the Predicament of Mankind. Earth Island, London. https://doi.org/10.1349/ ddlp. 1

Munholland, J. K. 2005, Rock of Contention: Free French and Americans at War in New Caledonia, 19401945. Berghahn Books, New York.

Murphy, K. 2012, 'The Social Pillar of Sustainable Development: A Literature Review and Framework for Policy Analysis,' Sustainability: Science, Practice E Policy, vol. 8, no. 1: 15-29.

Murphy, M. 2015, 'Unsettling Care: Troubling Transnational Itineraries of Care in Feminist Health Practices,' Social Studies of Science, vol. 45, no. 5: 717-737. https://doi.org/10.1177/0306312715589136

Newman, K., Fisher, S., Mayhew, S. \& Stephenson, J. 2014, 'Population, Sexual and Reproductive Health, Rights and Sustainable Development: Forging a Common Agenda,' Reproductive Health Matters, vol. 22, no. 43: 53-64. https://doi.org/10.1016/S0968-8080(14)43770-4

Pascual, F. C. 2017, 'Le Musée du bagne en Nouvelle-Calédonie et ses constructions identitaires' [The Penal Colony Museum in New Caledonia and its Identity Constructions], Communities Acting for Sustainability in the Pacific Special Issue, guest edited by A. Bissonauth \& R. Ward. Portal Journal of Multidisciplinary International Studies, vol. 14, no. 2 (September): 1-16. http://dx.doi.org/10.5130/portal. $\underline{\mathrm{v} 14 \mathrm{i} 2.5335}$

Petchesky, R. P. 1995, 'From Population Control to Reproductive Rights: Feminist Fault Lines,' Reproductive Health Matters, vol. 3, no. 6: 152-161. https://doi.org/10.1016/0968-8080(95)90172-8

Puig de la Bellacasa, M. 2010, 'Ethical Doings in Naturecultures,' Ethics, Place E Environment, vol. 13, no. 2: 151-169. https://doi.org/10.1080/13668791003778834

Puig de la Bellacasa, M. 2011, 'Matters of Care in Technoscience: Assembling Neglected Things,' Social Studies of Science, vol. 41, no. 1: 85-106. https://doi.org/10.1177/0306312710380301

Puig de la Bellacasa, M. 2012, “Nothing Comes without Its World”: Thinking with Care,' The Sociological Review, vol. 60, no. 2: 197-216. https://doi.org/10.1111/j.1467-954X.2012.02070.x

Puig de la Bellacasa, M. 2015, 'Making Time for Soil: Technoscientific Futurity and the Pace of Care,' Social Studies of Science, vol. 45, no. 5: 691-716. https://doi.org/10.1177/0306312715599851

Redclift, M. 2005, 'Sustainable Development (1987-2005): An Oxymoron Comes of Age,' Sustainable Development, vol. 13, no. 4: 212-227. https://doi.org/10.1002/sd.281

Richie, C. 2015, 'What Would an Environmentally Sustainable Reproductive Technology Industry Look Like?,' Journal of Medical Ethics, vol. 41, no. 5: 383-387. http://jme.bmj.com/content/41/5/383. http:// dx.doi.org/10.1136/medethics-2013-101716

Ris, C. 2013, 'Les inégalités ethniques dans l'accès a l'emploi en Nouvelle-Calédonie' [Ethnic Inequalities in Employment Access in New Caledonia], Economie et Statistique, vol. 464, no. 1: 59-72. https://doi. org/10.3406/estat.2013.10229

Robert, K. W., Parris, T. M. \& Leiserowitz, A. A. 2005, 'What Is Sustainable Development? Goals, Indicators, Values, and Practice,' Environment: Science and Policy for Sustainable Development, vol. 47, no. 3: 8-21. https://doi.org/10.1080/00139157.2005.10524444

Salomon, C. 2000a, 'Hommes et emmes: Harmonie d'ensemble ou antagonism sourd?,' [Men and Women: Harmony Together or Deaf Antagonism?] in En pays kanak; Ethnology, linguistique, archéology, histoire de la Nouvelle Calédonie [In Kanak Country; Ethnology, Linguistics, Archaeology, History of New 
U T S

e PRES S

Caledonia], (eds) A. Bensa \& I. Leblic. Maison des Sciences de l'Homme, Paris: 311-338. https://doi. org/10.4000/books.editionsmsh.2799

Salomon, C. 2000b, Savoirs et pouvoirs thérapeutiques Kanaks [Kanak Therapeutic Knowledges and Powers]. PUF, Paris.

Salomon, C. 2002, 'Obligatory Maternity and Diminished Reproductive Autonomy in A'Jië and Paicî Kanak Societies: A Female Perspective,' in Birthing in the Pacific: Beyond Tradition and Modernity?, (eds) V. Lukere \& M. Jolly. Honolulu, University of Hawai'i Press: 79-99.

Salomon, C. 2003, 'Quand les filles ne se taisent plus. Un aspect du changement postcolonial en Nouvelle-Calédonie' [When Girls No Longer Remain Quiet. A Dimension of Post-colonial Change in New Caledonia], Terrain, no. 40: 133-150. https://doi.org/10.4000/terrain.1573

Sandbach, F. 1978, 'The Rise and Fall of the Limits to Growth Debate,' Social Studies of Science, vol. 8, no. 4: 495-520. https://doi.org/10.1177/030631277800800404

Schrader, A. 2015, 'Abyssal Intimacies and Temporalities of Care: How (Not) to Care About Deformed Leaf Bugs in the Aftermath of Chernobyl,' Social Studies of Science, vol. 45, no. 5: 665-690. https://doi. org/10.1177/0306312715603249

Shineberg, D. 1986, French Colonization in the Pacific: With Special Reference to Nerw Caledonia In Australia and the Pacific Sydney. H. V. Evatt Memorial Foundation, Sydney.

Shineberg, D. 1999, The People Trade: Pacific Island Laborers and New Caledonia, 1865-1930. University of Hawai'i Press, Honolulu.

Smail, J. K. 2002, 'Confronting a Surfeit of People: Reducing Global Human Numbers to Sustainable Levels an Essay on Population Two Centuries after Malthus,' Environment, Development and Sustainability, vol. 4, no. 1: 21-50. https://doi.org/10.1023/A:1016327316754

Spar, D. L. 2006, The Baby Business: How Money, Science, and Politics Drive the Commerce of Conception. Harvard Business School Press, Boston.

Springett, D. 2005, 'Critical Perspectives on Sustainable Development,' Sustainable Development, vol. 13, no. 4: 209-211. https://doi.org/10.1002/sd.279

Strathern, M. 1992, Reproducing the Future: Essays on Anthropology, Kinship and the New Reproductive Technologies. Manchester University Press, Manchester.

Tjibaou, J.-M. 1996, La presence Kanak [The Kanak Presence]. Odile Jacob, Paris.

Tronto, J. C. 1995, 'Care as a Basis for Radical Political Judgments,' Hypatia, vol. 10, no. 2: 141-149. https://doi.org/10.1111/j.1527-2001.1995.tb01376.x

Turner, G. M. 2008, 'A Comparison of the Limits to Growth with 30 Years of Reality,' Global Environmental Change, vol. 18, no. 3: 397-411. https://doi.org/10.1016/j.gloenvcha.2008.05.001

UNESCO n.d., Sustainable Development Goals for Culture on the 2030 Agenda. Online, available: http://en.unesco.org/sdgs/clt [Accessed 5 February 2017].

United Nations 1987, Report of the World Commission on Environment and Development: Our Common Future (or Brundtland Report). Online, available: http://www.un-documents.net/wced-ocf. htm [Accessed 5 February 2015].

United Nations 1994, Report of the International Conference on Population and Development. A/ CONF.171/13. Online, available: https://www.unfpa.org/sites/default/files/event-pdf/icpd eng 2.pdf [Accessed 15 May 2017]. 
United Nations 2015a, Sustainable Development Goals. Online, available: http://www.un.org/ sustainabledevelopment/sustainable-development-goals/[Accessed 5 February 2017].

United Nations 2015b, Transforming Our World: The 2030 Agenda for Sustainable Development. Online, available: http://www.un.org/ga/search/view doc.asp?symbol=A/RES/70/1\&Lang=E [Accessed 5 February 2017].

United Nations 2016, Resolution Adopted by the General Assembly on 6 December 2016 on the Report of the Special Political and Decolonization Committee (Fourth Committee) (A/71/502). Online, available: http://www.undocs.org/A/RES/71/119 [Accessed 28 June 2017].

Vallance, S., Perkins, H. C. \& Dixon, J. E. 2011, 'What Is Social Sustainability? A Clarification of Concepts,' Geoforum, vol. 42, no. 3: 342-348. Online, available: http://www.sciencedirect.com/science/ article/pii/S0016718511000042?via\%3Dihub [Accessed 28 June 2017]. 